\title{
ZONAL EVALUATION FOR SITING A SOLAR POWER PLANT IN CROSS RIVER STATE, NIGERIA.
}

\section{FAITHPRAISE, FINA. O AND EDOHOEKET, SAMUEL T.}

\author{
(Received 4 April 2016; Revision Accepted 10 June 2016)
}

\begin{abstract}
An experimental survey was embarked upon to establish the effect of solar radiation intensity, the panel power output, current density and the efficiency of solar panels in three major geographical zones in Cross River State, Nigeria. The zones are Mangrove, University of Calabar, Tropical Rainforest, Nko - Yakurr and Guinea Savanna, Abakpa - Ogoja. The result from the investigation shows that the Guinea Savanna produced the highest current density of $8.20 \mathrm{~A} / \mathrm{cm}^{2}$, power output of $152.3 \mathrm{~W}, 36.5 \%$ efficiency and a solar radiation magnitude of $991.9 \mathrm{~W} / \mathrm{m}^{2}$ from a monocrystalline panel. However, polycrystalline panel generated better output for all the measured parameters thus: current density of $8.80 \mathrm{~A} / \mathrm{cm}^{2}$, power output of $170.72 \mathrm{~W}, 39.9 \%$ efficiency range for the same solar radiation magnitude of $991.9 \mathrm{~W} / \mathrm{m}^{2}$. From the analysis of the survey performed across the three geographical zones. The Mangrove zone has shown greater potential to accommodate solar farms, hence generate good energy to bridge the vacuum created in the power generating sector.
\end{abstract}

KEYWORDS: Epileptic supply, mangrove zone, solar farm, output power, panels efficiency.

\section{INTRODUCTION}

Due to the poor and unreliable supply of electric power in major towns and villages in Cross River State, SouthSouth, Nigeria, it is desirable to find a lasting solution to the sources of electrical power generation. Weighing the various sources of electrical energy generation in Nigeria, the researcher proposed the use of renewable (solar) energy in particular, as a lasting solution to the intermittent electrical power supply witness everywhere in Nigeria. Solar power is the transformation of energy from sunlight into electricity, by the use of photovoltaics (PV), or by the use of lenses and tracking systems that concentrated a large surface area of sunlight into a small beam. Photovoltaic (PV) solar cells convert sunlight into electricity, by absorbing

solar radiation within the $p-n$ semiconductor and transforming photons into electrical energy by producing electron-hole pairs that generate a voltage and a current flow. As acknowledged in the works of (Sharan, 2008) solar energy has free infinite source of energy with the competence to provide an alternative energy devoid of environmental pollution, with the capacity to decrease the rate of depletion of energy reserves without damaging the ozone layer. Photovoltaic are solid state devices that simply make electricity out of sunlight silently with little to no maintenance and depletion of material resources (Deo and Mark, 2005).

The design of the PV system relies on the input of measured data close to the site of the installation which is daily and yearly variation due to the apparent motion of the sun, and irregular variations due to the weather condition or cloud cover (Markvart, 1994), (DE Bassey et al, 2016). PV technologies have different seasonal patterns of behavior due to the variations in spectral response (Carr and Pryor, 2004), (Mfon and Fina, 2016). This confirmed that modules of differing technologies could be more suited to specific climates. The a-Si array in a tropical climate can

produce up to $20 \%$ more energy with high ambient temperatures and high humidity during the wet season, than the p-Si array (Mieke, 1998). The a-Si modules is observed to be more suited to tropical climates (Akhmad et al, 1997). In better performance ratio (Nowshad et al, 2009) placed amorphous silicon and copper Indium Diselenide (CIS) solar cell to mono-and multi-crystalline silicon solar cells in Malaysia due to the climatic conditions.

It is against this background that we decided to use two different commercial PV modules commonly found within the state and taking into consideration the three vegetation of the Cross River State, so as to determine the best location for the solar farm taking into consideration some parameters like the effect of solar radiation intensity, the output power, the current density and the efficiency of the solar panels.

\section{Related works}

(Joseph and Faithpraise, 2016) "Experimentally demonstrated that the power generated by a photovoltaic panel depends on both the intensity of the sunlight and on the angle of its inclination towards the

Faithpraise. Fina. O., Electronic and Computer Technology Unit, Physics Department, University of Calabar, Calabar. Edohoeket, Samuel T., Computer Engineering, Faculty of Engineering and Technology, University of Calabar, Calabar. 
sun. The power performance can be enhanced when a photovoltaic panel is inclined at an angle of between $40^{\circ}$ to $50^{\circ}$ where the photovoltaic panel assumes a position directly in phase with the sun than any other". Relative humidity affects efficiency of solar panel as it affects the current of solar panels and shows little effect on the output voltage Ettah et al, 2012). Light intensity has a dominant effect on current parameters (El-shaer et al, 2014).

(Chow, 2007) states "short circuit current and maximum current are increased linearly with increasing light intensity. So, the maximum output power density increased by $80 \%$ with increasing light intensity from 0.2 sun to 1.0 sun. It was also observed that module temperature has a dramatic effect on voltage parameters.

Open circuit voltage and maximum voltage are decreased with increasing module temperature. Therefore the maximum output power density decreased by $25 \%$ and $14 \%$ for the monocrystalline and polycrystalline silicon with increasing the module temperature from $10^{\circ} \mathrm{C}$ to $50^{\circ} \mathrm{C}$ ". Energy will forever remain the basic foundation which determines the stability of the economic development of any nation (Chow, 2007). For academic and economic activities to thrive and grow, the daily power supply must be continuous and permanent (Faithpraise et al, 2017a). The researcher further decry the change of attitude and fraud elimination as a major player to improve energy efficiency (Faithpraise et al, 2017b); (Faithpraise et al, 2018) in energy utilization. In order to accent the importance of solar energy (Jager-Waldau, 2002) expressed fear on fossil fuel reserves constraint and shrinking and therefore developed more efficient methods of producing energy from alternative sources. (Rabah, 2005) states that the increased use and promotion of renewable energy technologies seem to provide viable solutions to environmental problems caused by other energy sources. (Bala et al. 2000), (Joseph, et al. 2016) $)^{a}$, (Joseph, et al. 2016) experimented that module performance varies with location of use and actual environmental conditions, which they are subjected to, as a result of variation in air mass, and other meteorological parameters of the local environment such as irradiation (solar flex), temperature, relative humidity and wind speed.

PV modules are durable, long lasting, environmentally friendly and cost efficient compared to the amount spend on fossil fuel. For instance solar panels are very useful in the manufacturing of battery chargers and cash reserves as illustrated in (Faithpraise et al, (2016) and (Faithpraise et al, 2018) ${ }^{a}$. Due to the modular nature of
PV systems, it can be designed to meet any electrical requirement no matter the size of the device or its appearance. It also can be connected to an electricity distribution system (grid-connected) or standalone (offgrid). Most PV's are durable with a warranty period of 25 years and with proper maintenance can attain a life span of 50 years. They are designed to withstand severe weather such as extreme heat, hail stone, snow and cold.

\section{Site Survey and Data Collection}

Data collection was done in specific locations across the three vegetation zones within cross River State. University of Calabar, for the mangrove vegetation, data gathering was done in University of Calabar Campus; Nko was used for the Tropical Rainforest and Abakpa for the Guinea Savanna.

Initial readings were collected on the two types of PV module using different measuring instruments, while monitoring the module output performance, the current and voltages were measured as well. Solar radiation which is one of the meteorological parameters were recorded. Data collections were made at hourly time intervals between the hours of 6:00am to 6:00pm all day long in each of the different locations across the three vegetation to ensure effective and accurate data records. The modules (monocrystalline and polycrystalline) and the meteorological sensors were placed on the same horizontal test plane. All the measuring instruments (photometer, multi-meter, charge controller) were connected in parallel with the PV modules. Finally, the coordinate readings were also taken in each of the locations to give it spatial information. The solar panel was theoretically enhanced by positioning it perpendicular to the sun's rays. The coordinate location of the test site for the three zones were: latitude: $4.9517 \mathrm{~N}$, Longitude $8.322 \mathrm{E}$, height above sea level: $140 \mathrm{~km}$ for mangrove vegetation; latitude: 5.87577N, Longitude 8.18982E, height above sea level: $7.93 \mathrm{~km}$, Tropical Rainforest and Latitude: $6^{\circ} 39^{\prime}$ $10.19 " \mathrm{~N}$, Longitude: $8^{\circ} 47^{\prime} 30.59 " \mathrm{E}$, for Guinea Savanna.

\section{Result and Analysis}

After careful measurement of some basic parameters (solar radiation, output power, current density and efficiency) of the two types of Solar panels used in this zones, the following results shown in Table 1 to Table 6 were obtained. 
Table 1: Comparison of Solar Radiation in the three Zone

\begin{tabular}{|c|c|c|c|}
\hline $\begin{array}{l}\text { Time } \\
\text { Hours }\end{array}$ & $\begin{array}{l}\text { Solar Radiation } \\
\text { Mangrove } \\
\left(\text { Solar Rad }{ }_{m}\right)\end{array}$ & $\begin{array}{l}\text { Solar Radiation } \\
\text { Tropical Rainforest } \\
\left(\text { Solar } \operatorname{Rad}_{\mathrm{T}}\right)\end{array}$ & $\begin{array}{l}\text { Solar Radiation } \\
\text { Guinea Savanna } \\
\text { (Solar } \operatorname{Rad}_{\mathrm{g}} \text { ) }\end{array}$ \\
\hline $6.00 \mathrm{am}$ & 0 & 0 & 0 \\
\hline 7.00am & 50 & 0.4 & 95.7 \\
\hline $8.00 \mathrm{am}$ & 251 & 10.8 & 170 \\
\hline 9.00am & 514 & 68.6 & 761.4 \\
\hline 10.00am & 530 & 118.4 & 901 \\
\hline 11.00am & 317 & 276.6 & 294 \\
\hline $12.00 \mathrm{pm}$ & 501 & 300.9 & 991.9 \\
\hline $1.00 \mathrm{pm}$ & 782 & 576.5 & 941.2 \\
\hline $2.00 \mathrm{pm}$ & 290 & 361.4 & 283.2 \\
\hline $3.00 \mathrm{pm}$ & 83.5 & 430.7 & 746.2 \\
\hline $4.00 \mathrm{pm}$ & 150 & 214.5 & 535.4 \\
\hline $5.00 \mathrm{pm}$ & 132 & 104.7 & 170 \\
\hline $6.00 \mathrm{pm}$ & 10.5 & 18.5 & 33.9 \\
\hline
\end{tabular}

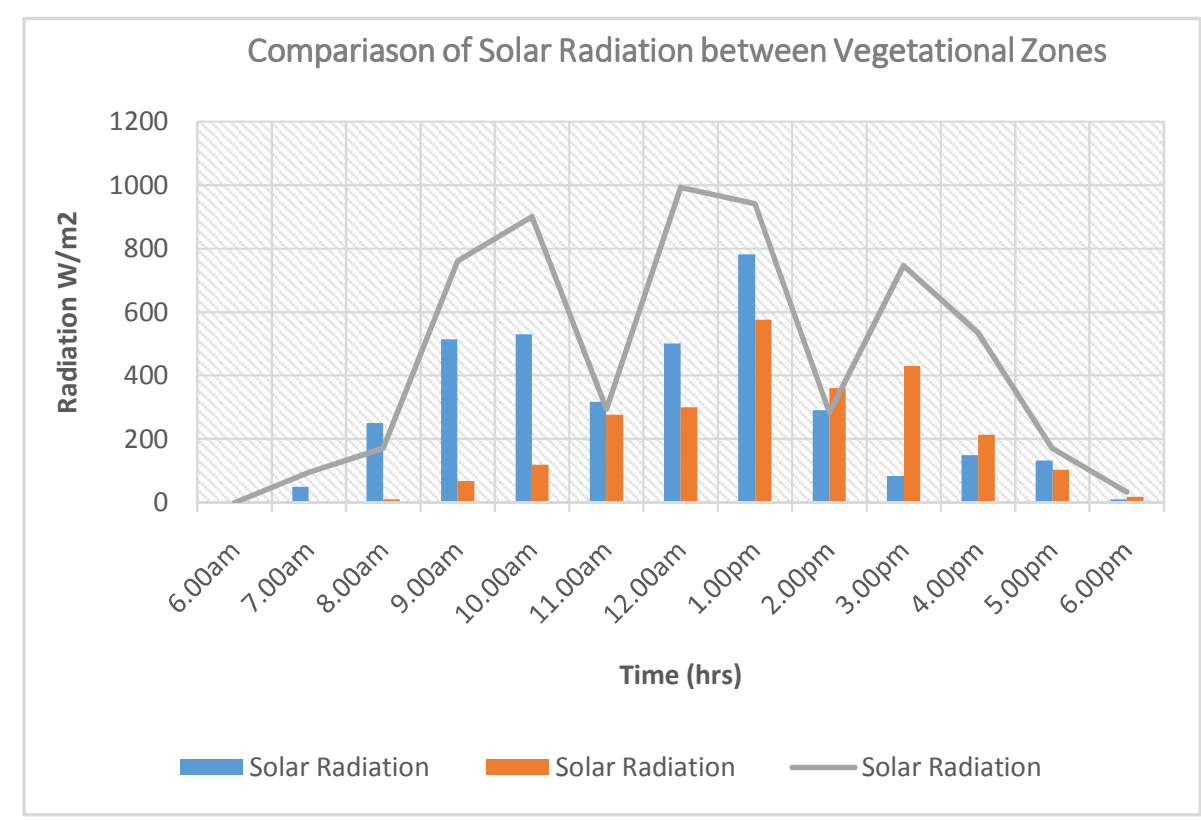

Fig. 1: Comparison of solar radiation across the cities in the three vegetation.

Table 1 and Figure 1, Shows the comparison of solar radiation across the cities in the three vegetation. Solar $\operatorname{Rad}_{\mathrm{m}}$ to represent solar radiation value in the Mangrove zone. Solar $\operatorname{Rad}_{\mathrm{T}}$ represent solar radiation value in the Tropical Rainforest zone and Solar $\operatorname{Rad}_{g}$ represent solar radiation value in the Guinea savanna zone 


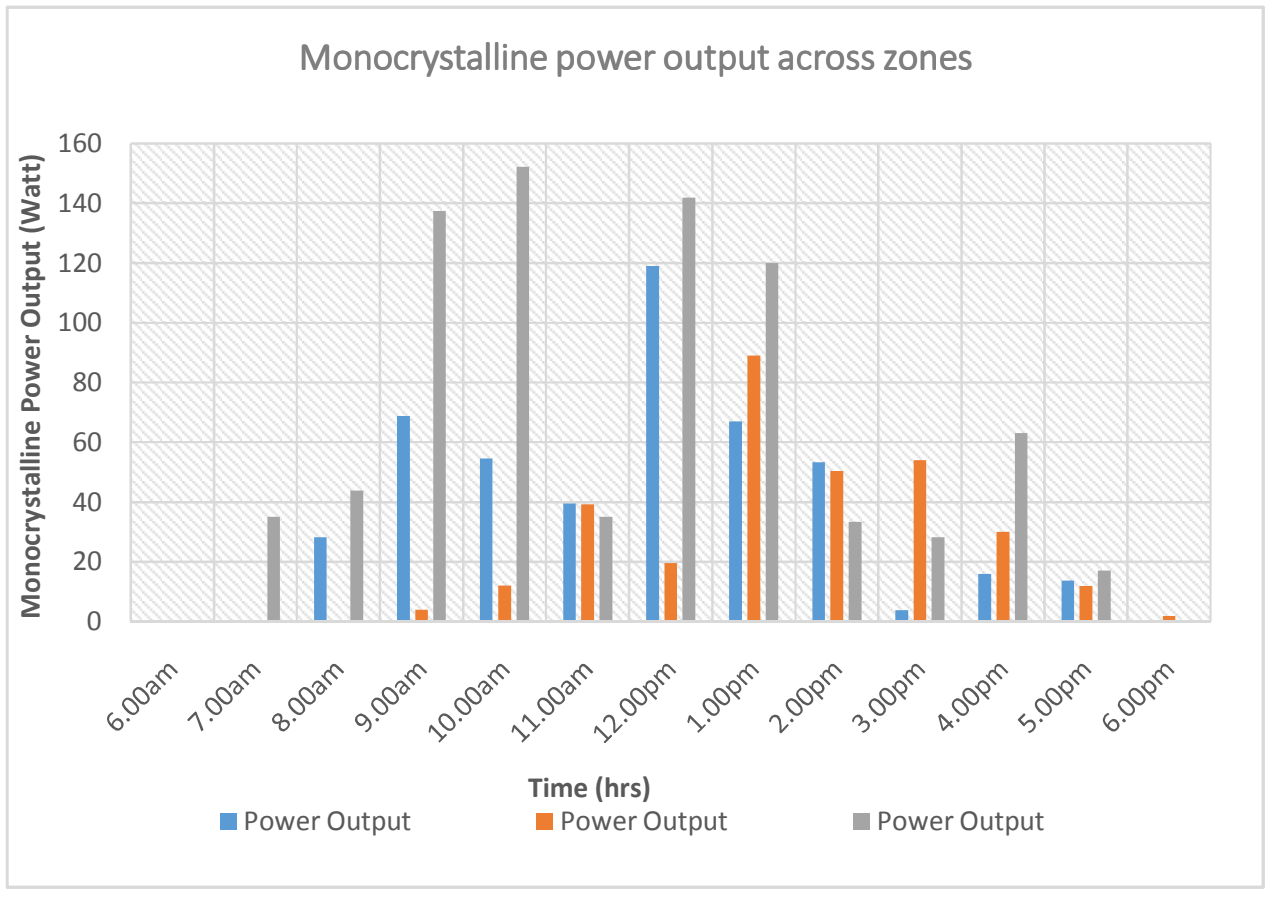

Fig. 2: Monocrystalline panel power output across the cities in the three vegetation.

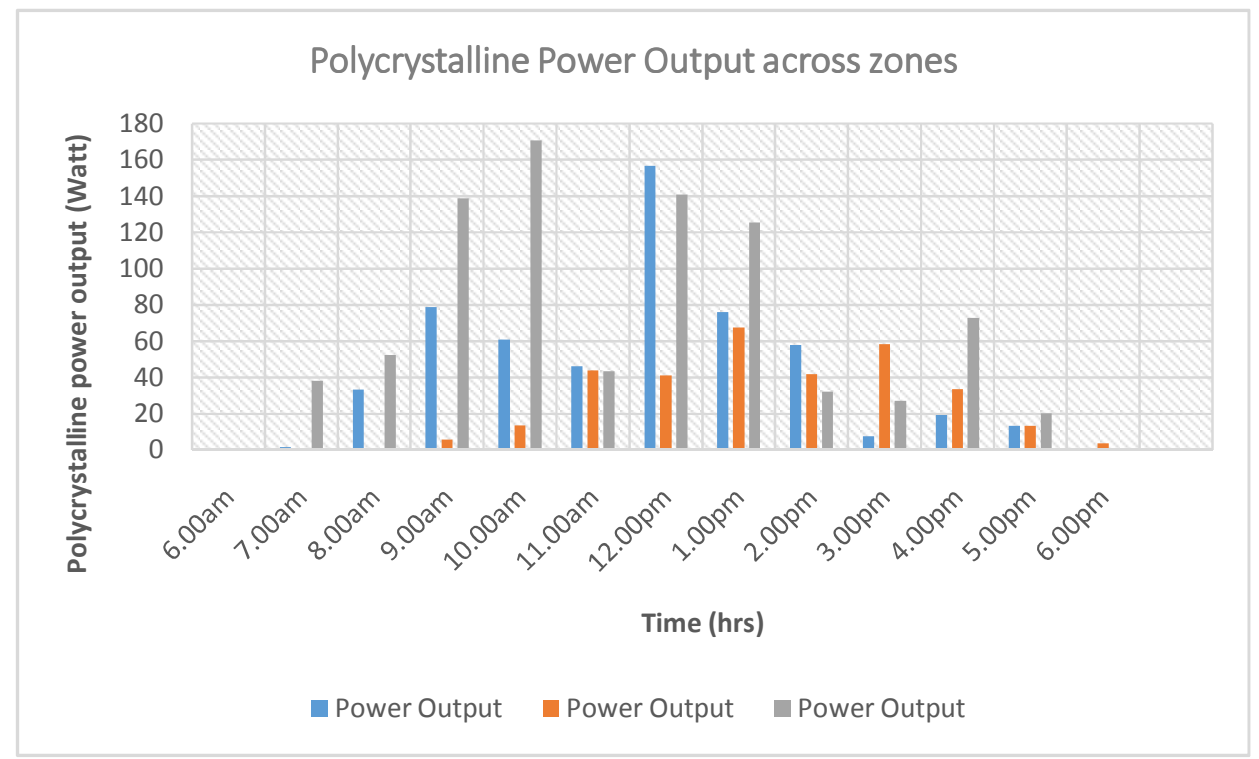

Fig. 3: Polycrystalline panel power output across the cities in the three vegetation. 
Table 2: Current Density between the Zones

\begin{tabular}{|c|c|c|c|}
\hline $\begin{array}{l}\text { Time } \\
\text { Hours }\end{array}$ & $\begin{array}{l}\text { current Density } \mathrm{A} / \mathrm{cm}^{2} \text { ) } \\
\text { Mangrove }\end{array}$ & $\begin{array}{l}\text { current Density }\left(\mathrm{A} / \mathrm{cm}^{2}\right) \\
\text { Tropical Rainforest }\end{array}$ & $\begin{array}{l}\text { current Density }\left(\mathrm{A} / \mathrm{cm}^{2}\right) \\
\text { Guinea savanna }\end{array}$ \\
\hline $6.00 \mathrm{am}$ & 0 & 0 & 0 \\
\hline 7.00am & 0 & 0 & 1.80072 \\
\hline 8.00am & 1.40056 & 0 & 2.20088 \\
\hline $9.00 \mathrm{am}$ & 3.40136 & 0.20008 & 6.80272 \\
\hline $10.00 \mathrm{am}$ & 2.70108 & 0.60024 & 7.503 \\
\hline $11.00 \mathrm{am}$ & 2.0008 & 1.90076 & 1.80072 \\
\hline $12.00 \mathrm{pm}$ & 6.10244 & 2.0008 & 7.20288 \\
\hline $1.00 \mathrm{pm}$ & 3.40136 & 4.40176 & 6.0024 \\
\hline $2.00 \mathrm{pm}$ & 2.60104 & 2.501 & 1.70068 \\
\hline $3.00 \mathrm{pm}$ & 0.20008 & 2.70108 & 1.40056 \\
\hline $4.00 \mathrm{pm}$ & 0.80032 & 1.5006 & 3.20128 \\
\hline $5.00 \mathrm{pm}$ & 0.70028 & 0.60024 & 0.90036 \\
\hline $6.00 \mathrm{pm}$ & 0 & 0.10004 & 0 \\
\hline
\end{tabular}

Table 2: Shows the value of Monocrystalline panel Current density across the cities in the three vegetation.

Table 3: Polycrystalline panel Current density across the cities in the three vegetation.

\begin{tabular}{|c|c|c|c|}
\hline $\begin{array}{l}\text { Time } \\
\text { Hours }\end{array}$ & $\begin{array}{l}\text { current Density } \mathrm{A} / \mathrm{cm}^{2} \text { ) } \\
\text { Mangrove }\end{array}$ & $\begin{array}{l}\text { current Density A } / \mathrm{cm}^{2} \text { ) } \\
\text { Tropical Rainforest }\end{array}$ & $\begin{array}{l}\text { current Density }\left(\mathrm{A} / \mathrm{cm}^{2}\right) \\
\text { Guinea savanna }\end{array}$ \\
\hline $6.00 \mathrm{am}$ & 0 & 0 & 0 \\
\hline $7.00 \mathrm{am}$ & 0.10004 & 0 & 2.0008 \\
\hline 8.00am & 1.70068 & 0 & 2.70108 \\
\hline $9.00 \mathrm{am}$ & 4.0016 & 0.30012 & 7.0028 \\
\hline $10.00 \mathrm{am}$ & 3.10124 & 0.70028 & 8.80352 \\
\hline $11.00 \mathrm{am}$ & 2.40096 & 2.20088 & 2.30092 \\
\hline $12.00 \mathrm{am}$ & 8.20328 & 2.10084 & 7.30292 \\
\hline $1.00 \mathrm{pm}$ & 3.90156 & 3.5014 & 6.5026 \\
\hline $2.00 \mathrm{pm}$ & 2.90116 & 2.10084 & 1.70068 \\
\hline $3.00 \mathrm{pm}$ & 0.40016 & 3.0012 & 1.40056 \\
\hline $4.00 \mathrm{pm}$ & 1.0004 & 1.70068 & 3.80152 \\
\hline $5.00 \mathrm{pm}$ & 0.70028 & 0.70028 & 1.10044 \\
\hline $6.00 \mathrm{pm}$ & 0 & 0.20008 & 0 \\
\hline
\end{tabular}


Table 3: Shows the value of the Polycrystalline panel Current density across the cities in the three vegetation.

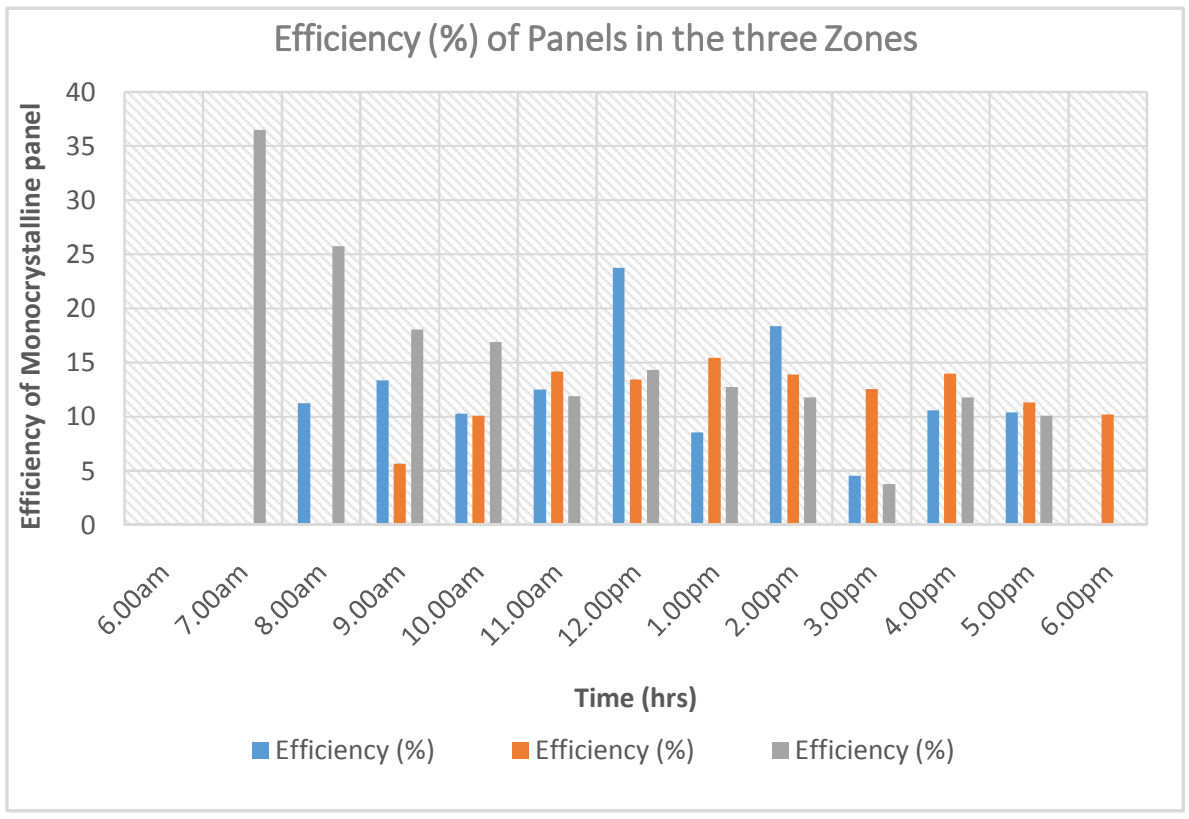

Fig. 4: Efficiency of Monocrystalline panel across the cities in the three vegetation.

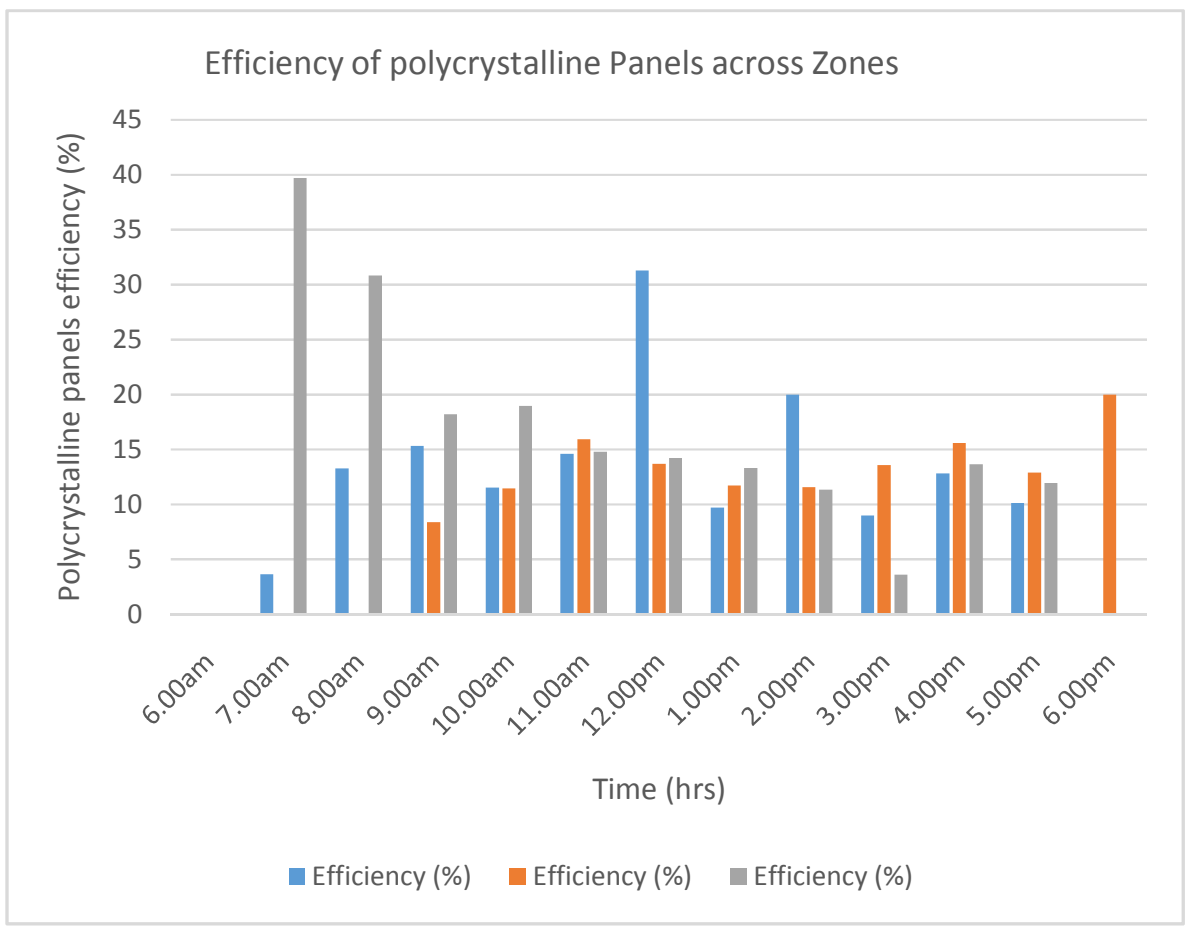

Fig. 5: Efficiency of Polycrystalline panel across the cities in the three vegetation. 
Tables 4. Efficiency of Polycrystalline Panel across zones

\begin{tabular}{|c|c|c|c|}
\hline $\begin{array}{l}\text { Time } \\
\text { Hours }\end{array}$ & $\begin{array}{l}\text { Efficiency } \\
(\%) \\
\text { Mangrove }\end{array}$ & $\begin{array}{l}\text { Efficiency } \\
(\%) \\
\text { Tropical } \\
\text { Rainforest }\end{array}$ & $\begin{array}{l}\text { Efficiency (\%) } \\
\text { Guinea savanna }\end{array}$ \\
\hline $6.00 \mathrm{am}$ & 0 & 0 & 0 \\
\hline 7.00am & 3.64146 & 0 & 39.7233 \\
\hline 8.00am & 13.2802 & 0 & 30.8241 \\
\hline $9.00 \mathrm{am}$ & 15.3369 & 8.39986 & 18.2106 \\
\hline 10.00am & 11.5273 & 11.4742 & 18.9554 \\
\hline 11.00am & 14.6178 & 15.9138 & 14.7916 \\
\hline 12.00pm & 31.274 & 13.6844 & 14.2097 \\
\hline $1.00 \mathrm{pm}$ & 9.72896 & 11.7219 & 13.3341 \\
\hline $2.00 \mathrm{pm}$ & 20.008 & 11.568 & 11.3499 \\
\hline $3.00 \mathrm{pm}$ & 9.00959 & 13.588 & 3.62246 \\
\hline $4.00 \mathrm{pm}$ & 12.8051 & 15.6193 & 13.6326 \\
\hline $5.00 \mathrm{pm}$ & 10.1328 & 12.9087 & 11.9754 \\
\hline $6.00 \mathrm{pm}$ & 0 & 20.008 & 0 \\
\hline
\end{tabular}

4.2.1 Analysis and Reliability of the Comparison The graph of Fig. 1 to Fig. 5 represent the measurements of all the parameters from the two panels in the three different vegetation.

Fig. 1 compares the solar radiation values of the panels in all the three zones. The results show that highest radiation value of $991.9 \mathrm{~W} / \mathrm{m}^{2}$ was recorded from the panels in the Guinea Savanna (Abakpa) location at $12.00 \mathrm{pm}$, followed by the Mangrove zone with $782 \mathrm{~W} / \mathrm{m}^{2}$ at $1.00 \mathrm{pm}$ and the Tropical Rainforest zone recorded the lowest of the peak radiation values of $576.5 \mathrm{~W} / \mathrm{m}^{2}$ at $1.00 \mathrm{pm}$. Table 1 also elucidates that the signal trend varies by time of the day across the three zones. For instance in the Guinea savanna the radiation signal though high was observed to start rising from 7.00am to $4.00 \mathrm{pm}$ and fluctuates in between the hours before it constantly drop to ' 33.9 ' at $6.00 \mathrm{pm}$. The same variation in signal trend were observed across the other vegetation zones.

Fig. 2, compares the power output of the monocrystalline panels of the three zones. The result shows that the highest power output of 152.3Watt at $10.00 \mathrm{am}$ was obtained from the monocrystalline panel in Guinea savanna, followed by the Mangrove zone with $118.9 \mathrm{Watt}$ at $12.00 \mathrm{am}$ and $88.9 \mathrm{Watt}$ at $1.00 \mathrm{pm}$ in the Tropical Rainforest zone respectively.

Fig. 3, shows the power output of the Polycrystalline panel across the three zones. 170.72Watt for Guinea savanna at $10.00 \mathrm{am}, 156.62 \mathrm{Watt}$ for Mangrove at $12.00 \mathrm{pm}$ and $67.6 \mathrm{~W}$ att for the Tropical Rainforest zone at $1.00 \mathrm{pm}$ respectively were the maximum values obtained from the panels.

Comparing the results of Fig. 2 and Fig. 3 shows the polycrystalline panel in the Guinea savanna has the highest power output value followed by the polycrystalline panel of the Mangrove zone and monocrystalline panel of the Tropical Rainforest zone respectively. It is also important to state that the signal trend was never constant as it varies between the times of the day from $6.00 \mathrm{am}$ to $6.00 \mathrm{pm}$.

Table 2, shows the current density obtained from the Monocrystalline panel across the three zones. The highest current density of $7.503 \mathrm{~A} / \mathrm{cm}^{2}$ was obtained from the Guinea savanna zone at $10.00 \mathrm{am}$, followed by 6.10 $\mathrm{A} / \mathrm{cm}^{2}$ for the Mangrove zone at $12.00 \mathrm{pm}$ and $4.40 \mathrm{~A} / \mathrm{cm}^{2}$ at $1.00 \mathrm{pm}$ for the Tropical Rainforest zone respectively.

Table 5, shows the current density obtained from Polycrystalline panel across the three zones. $8.80 \mathrm{~A} / \mathrm{cm}^{2}$ was obtained at 10.00am from the Guinea savanna, $8.20 \mathrm{~A} / \mathrm{cm}^{2}$ at $12.00 \mathrm{pm}$ from the Mangrove zone and $3.50 \mathrm{~A} / \mathrm{cm}^{2}$ at $1.00 \mathrm{pm}$ from the Tropical Rainforest zone respectively.

Analysis of Table 4 and 5 , shows the polycrystalline having the highest current densities across the zones as the panel's current densities varies constantly across the zones and the time of day.

Fig. 4, shows the efficiency of monocrystalline panels measured across the three zones. The result displayed $36.5 \%$ at $7.00 \mathrm{am}, 23.8 \%$ at $12.00 \mathrm{pm}$ and $15.4 \%$ at $1.00 \mathrm{pm}$ respectively as the maximum values obtained from the Guinea savanna, the Mangrove and finally the Tropical Rainforest zone.

Fig. 5, depicts the efficiency of the Polycrystalline panels to be $39.73 \%$ at $7.00 \mathrm{am}, 31.2 \%$ at $12.00 \mathrm{pm}$ and $20.0 \%$ at $6.00 \mathrm{pm}$ respectively being the maximum values recorded for the Guinea savanna, the Mangrove and the Tropical Rainforest zone.

The analysis of Fig. 4 and 5 indicates that the efficiency of the polycrystalline panel is better across the three zones. Although a downward drift was observed 
throughout the time of the day. It is important to state that at Guinea savanna the efficiency acquired from the different panels kept dropping continuously from 7.00am to $6.00 \mathrm{pm}$. A trend that varies differently from the panels of other vegetation zones as observed in the figures. It was also observed that the efficiency of the polycrystalline panels in the Tropical rainforest increased geometrically abnormally at $6.00 \mathrm{pm}$. A major inference on the signal trend observed here demonstrates that efficiency varies with the time of the day, and it's never constant no matter what type of panels used in all the three zones

From the above result, we can endorse that efficiency is independent on solar radiation and power output of the panel. Hence the efficiency of solar panels (monocrystalline and polycrystalline) varies with the time of the day.

Mathematically, we infer that the efficiency of solar panels (monocrystalline and polycrystalline) in particular is inversely proportional to the time of the day. We express this mathematically as follows:

let $\varepsilon=$ efficiency

$t_{d}=$ time of the day

So that

$\varepsilon \propto \frac{1}{t_{d}}$

\section{CONCLUSION}

From the observation in this research work, the polycrystalline panels are the most suitable panels to build or establish a solar farm in most parts of the Cross River State. The most suitable zone to establish a solar grid from this research is Guinea Savanna due to the maximum Solar Radiation value of $991.9 \mathrm{~W} / \mathrm{m}^{2}$, the power output of 170.72 Watt, the current density of $8.80 \mathrm{~A} / \mathrm{cm}^{2}$ and the panel efficiency of $39.9 \%$ respectively measured from the panel in the Guinea savanna zone.

This result does not contradict the founding of Nowshad et al, (2009) whose world record for silicon based PolyVoltalic (PV) is $27.6 \%$. His result was generalised world average value of efficiency for PV.

The $39.9 \%$ efficiency recorded in this research as shown in Table 4, is perculiar to a specific PV panel, zone, location and time duration. Therefore feature research should be performed in this area using triple junction technology (TJT) modules. Cross River is a virgin state in terms of renewable energy investment. Investors are therefore expected to exploit this area of renewable energy generation.

\section{REFERENCES}

Akhmad, K., Kitamura, A., Yamamoto, F., Okamoto, H., Takakura, H., and Hamakawa Y., 1997. Outdoor performance of a-Si and p-Si modules. Solar Energy Materials and Solar Cell. 46, 209-218

Azhar G., 2012. The performance of Three Different Solar panels for Solar Electricity Applying solar Tracking Device under the Malaysian Climate Condition. . Energy and environment Research , 2, 235-243.
Bala, E. J.; Ojosu, J. O. and Umar, I. H., 2000 Government Policies and programmes on the Development of PV subsector in Nigeria. Nigeria Journal of Renewable energy (8) 1 and 2, 1 -6

Carr, A., and Pryor, T., 2004. A comparison of the performance of different PV module types in temperate climates. Retrieved 26th June, 2006 from Solar Energy: http://dx.doi.10.1016/j.solener.2003.07.02

Chow, T. T. He, J. J. and Chan A. L., 2007: Performance Evaluation of Photovoltaic Thermosyphon System for Subtropical Climate

Davud, M., and N., D., 2015. The Effect of Solar Radiation and Temperature on solar Cell Performance. Extensive Journal of Applied Sciences.

Deo, P., and Mark, S., 2005. Designing with Solar Power: A Source Book for Building Integrated Photovoltaic (BiPV). London:Earthscan , 23.

D. E. Bassey, B. E. Okon, F. O. FaithPraise, E. E. Eyime 2016 Characterization of Traffic Flow Consumption Pattern and Subscribers' Behaviour. International Journal of Innovative Research in Computer and Communication 4(5) 10

Dincar, I., 2003: The Role of Energy in Energy Policy Making. Energy Policy Vol.

(30):137-149

El-Shaer, A., Tadros, M., and Khalifa, M. 2014. Effect of Light Intensity and Temperature Parameters on Crystalline Silicon Solar Modules

Parameters. Science Direct. , 8, 311-318.

Ettah, E., Udoimuk, A., Obiefuna, j., and Opara, E., 2012. Effect of relative humidity on the efficiency of solar panels in Akamkpa, Nigeria. Universal journal of management and solar sciences , 2 (3).

Faithpraise, F.O, Johnson, Samuel Nelson, Mfon, Charles (2018) Multipurpose Voltage Solar Charger (MVSC) with patent number NG/P/2018/295

Mfon O. Charles, Fina O. Faithpraise. Observed Variations in HF Propagation Over A Path Aligned Along the Mid-Latitude Trough. IOSR Journal of Electronics and Communication Engineering (IOSR- JECE) e-ISSN: 22782834,p- ISSN: 2278-8735.Volume 11, Issue 3, Ver. II (May-Jun.2016), PP 76-86 www.iosrjournals.org DOI: 10.9790/28341103027686 www.iosrjournals.org

Fina O. Faithpraise, Mfon Charles, Faithpraise B. otosi, Linda Nwaeto, Chris Chatwin. "A Survey on the Status of Solar Energy Utilization within the Tertiary Institutions in Calabar," International Journal of Scientific and Engineering Research 
Volume 8, Issue 6, June-2017 ISSN 2229-5518.

$\mathrm{Pp}$ 593-603. 2017. IJSER @ 2017

http://www.ijser.org France (Google Scholar)

Fina O. Faithpraise ${ }^{a}$, Effiong O. Obisung, Azele, E.

Peter, Chris R. Chatwin "Attitudinal change: a major therapy for non-technical losses in the Nigerian power sector" Proceedings of 2018 Conference: Electrical, Computer and Communication Engineering 2018 London in press

Faithpraise Fina, Bassey Donatus, Charles Mfon, Osahon Okoro, Udoh Monday, Chatwin Chris Experimental Design and Construction of an Enhanced Solar Battery Charger. IOSR Journal of Electrical and Electronics Engineering (IOSR-JEEE) e-ISSN: 2278-1676,p- ISSN: 2320-3331, Volume 11, Issue 2 Ver. III (Mar. Apr. 2016), PP 11-16 www.iosrjournals.org DOI:10.9790/1676-1102031116 www.iosrjournals.org New York (Google Scholar)

Guha, S., ang, J. and Banerjee, A., 2000 . Amorphous Silicon Alloy Photovoltaic Research. Past, Present and Future. Website (http://www.red.herring.com)

Jager-Waldau A. 2002: Status of PV Research, Solar Cell Production and Market Implementation

Japan, USA and European Union. EUR 20425 EN European Commissions, Joint Research Center.

Joseph Amajama and Faithpraise Fina. "Impact of Angle of Photovoltaic Panels' Inclination on Its Output Power," Journal of Scientific and
Engineering Research, 2016, 3(4):73-77 ISSN: 2394-2630, CODEN (USA) JSERBR (Google Scholar)

Joseph Amajamaa, Faithpraise Fina, Samuel Eyeh Mopta Variations of Tropospheric Radio Wave Refractivities across Southern Nigeria - the Rainforest to Mangrove. International Journal of Science, Engineering and Technology Research (IJSETR) Volume 5, Issue 6, June 2016 ISSN: $2278-7798$

Joseph Amajamab, Samuel Eyeh Mopta, Faithpraise Fina. Variation of tropospheric radio wave refractivities across northern Nigeria - the Savannah. International Journal of Engineering Research and General Science Volume 4, Issue 3, May-June, 2016. ISSN 2091-2730

Markvart, T., 1994. Solar Electricity. West Sussex: John Wiley and Sons. P.I.

Mieke, W., 1998. Hot climate performance comparison between polycrystalline and amorphous silicon cells connected to a utility mini-grid. 36th Annual Conference of the Australian and New Zealand Solar Energy Society. Christ Church.

Nowshad, A., Chin, W. L., and Kamaruzzaman, S., 2009. A practical field study of various solar cells on their performance in Malaysia. Renewable Energy , 34, 1939-1946.

Rabah, K. V. O., 2005: Integrated Solar Energy System for Rural Electrification in Kenya, Renewable Energy Vol.(30)23-42 